\title{
EKSISTENSI ISTIHSAN DALAM ISTINBATH HUKUM MENURUT PERSFEKTIF IMAM HANAFI
}

\author{
Winarno \\ STAIN Syaikh Abdurrahman Siddik Bangka Belitung
}

\begin{abstract}
In this case talked about concideration about Islam law development in it's accelaration and this case appear in modern time. The Research in this journal is the exprolation of the real thing that have done by Imam Hanafi. This research is a library research by taking and collecting data from the literature that correlleted with problem and how to discuss. The data of this research is kwalitative data that correlated with Imam Hanafi's think about Istihsan.

The result of this research showed that, Istihsan method excistence. In law Istinbath that used by Imam Hanafi is developing from Qiyas Khofi method, whereas this method is trying to look for one of Dalil (rules) from two Dalil (reules) that againts with other Dalil because it can get more achive the purpose of law form. So every case / problem that faced can have solution.
\end{abstract}

Key Words: Excistantion, Method, Law, Istihsan.

\section{A. Pendahuluan}

Memasuki abad kedua Hijriyah merupakan masa gerakan pemikiran hukum Islam secara besar-besaran dan meluas di berbagai kawasan. Hal ini, tidak lain karena di samping para ulama atau fuqaha mempunyai kesungguhan dalam menggali hukum, juga para khalifah Bani Abbas mempunyai perhatian dan minat yang besar terhadap hukum Islam dan fuqaha. Para tokoh, seperti Imam Hanafi (w. 150 H), Imam Malik (w. 179 H), Imam Ahmad Ibnu Hambal (w. 241 H), Imam Syafi'i (w. 204 H) dan lainnya, masing-masing menawarkan 
kerangka metodologi, teori dan kaidah-kaidah ijtihad yang menjadi pijakan mereka dalam menetapkan hukum. Pada awalnya para imam mazhab ini hanya bertujuan untuk memberikan jalan dan merupakan langkah-langkah dalam memecahkan berbagai macam persoalan hukum yang di hadapi, baik itu dalam memahami nash Al-Qur'an dan hadis maupun kasus hukum yang tidak ditemukan jawabannya dalam nash. ${ }^{2}$

Mengenai dasar istinbath hukum para ulama mazhab sepakat bahwa AlQur'an dan hadis merupakan sumber utamanya. Akan tetapi mereka berbeda pendapat dalam sumber istinbath hukum dari selain Al-Qur'an dan hadis tersebut. Salah satu sumber yang diperselisihkan tersebut adalah mengenai istihsan.

Menurut istilah para ahli hukum, istihsan diartikan dengan dua makna yaitu: Pertama, mempergunakan ijtihad dan segala daya pikir dalam menentukan sesuatu yang urusannya oleh syara' diserahkan kepada pendapatpendapat kita sendiri. Kedua, dalil yang menyaingi qiyas atau meninggalkan qiyas dan menetapkan apa yang lebih bermanfaat bagi manusia. ${ }^{3}$

Maka makna istihsan yang pertama tak ada seorang pun yang menolaknya. Sedangkan makna istihsan dalam pengertian yang kedua, itulah yang diperselisihkan tentang boleh tidaknya kita mempergunakannya, sebagaimana ulama berbeda-beda pendapat pula dalam menentukan definisinya.

Di antara ulama mazhab yang mempergunakan istihsan sebagai dasar istinbath hukum adalah Imam Hanafi, Imam Maliki dan Imam Hambali. Ketiga imam ini mempergunakan istihsan baik secara teoritis maupun secara praktis, namun Imam Syafi'i mempergunakan istihsan hanya dalam tataran praktis, sedangkan dalam tataran teoritis imam Syafi'i tidak mempergunakan istihsan,

\footnotetext{
${ }^{2}$ Romli SA., Muqaranah Mazahib Fil Ushul, (Jakarta: Gaya Media Pratama, 1999), hal. 2.

3 T.M. Hasbi Al-Shiddieqy (a), Falsafah Hukum Islam, (Semarang: PT. Pustaka Rizki Putra, 2001), hal. 286.
} 
hal ini terlihat ketika ia menolak mengenai definisi istihsan yang di kemukakan oleh pengikut mazhab Imam Hanafi. ${ }^{4}$

Menurut Imam Hanafi penggunaan istihsan sebagai hujjah karena berdasarkan penelitian terhadap berbagai kasus dan penerapan hukumnya, ternyata berlawanan dengan ketentuan qiyas atau ketentuan kaidah umum, di mana kadang-kadang dalam penerapannya terhadap sebagian kasus tersebut justru bisa menghilangkan kemaslahatan yang dihajatkan oleh manusia, karena kemaslahatan itu merupakan peristiwa khusus.

\section{B. Pengertian Istihsan}

Bila diteliti dasar perumusan dan akar sejarah munculny istihsan sebagai dalil hukum adalah berawal dari persoalan qiyas. Qiyas sebagai salah satu dalil hukum dalam persoalan-persoalan tertentu tidak dapat diterapkan, karena salah satu dari unsur rukunnya yaitu 'illat tidak memenuhi syarat. Dengan kata lain, 'illat qiyas yang akan dijadikan sebagai pautan atau penyamaan hukum bagi persoalan tertentu itu tidak dapat diterapkan, karena tidak sebanding. ${ }^{5}$ Oleh karena itu, harus diselesaikan dengan cara lain yang lebih mendekati tujuan syara'. Dasar pemikiran dan perumusan istihsan seperti ini, yang kemudian diangkat sebagai salah satu dalil hukum. Pada mulanya dimunculkan oleh Imam Hanafi di kalangan para pengikutnya.

Istihsan adalah sumber hukum yang banyak dipakai dalam terminologi dan istinbath hukum oleh dua imam mazhab, yaitu Imam Malik dan Imam Hanafi. Bahkan Imam Malik menilai, pemakaian istihsan merambah 90\% dari seluruh ilmu figh, sementara itu, murid-murid Imam Hanafi, seperti diceritakan Muhammad bin Hasan, tidak sejalan dengan gurunya. Istihsan dipandang tidak jelas kriterianya. Apabila Imam Hanafi berkata: "pakailah istihsan", maka tidak

\footnotetext{
${ }^{4}$ Satria Effendi, Ushul Fiqh, Cetakan Ke 5, (Jakarta: Kencana, 2014), hal. 143.

${ }^{5}$ Romli SA., Muqaranah Mazahib..., hal. 142.
} 
seorangpun murid-muridnya yang menuruti perintahnya. ${ }^{6}$ Pada dasarnya Imam Hanafi masih tetap menggunakan dalil qiyas, selama masih dipandang tepat. Namun jika pemakaian dalil itu pada situasi tertentu dinilai kurang tepat, maka ia beralih kepada dalil istihsan.

Menurut kamus bahasa Arab, istihsan berarti menganggap baik atau mencari yang baik. ${ }^{7}$ Lebih Abdul Wahab Khallaf menjelaskan bahwa istihsan menurut bahasa berarti menganggap baik sesuatu atau mengikuti sesuatu yang baik dalam hal yang nyata (konkret) atau tidak nyata (abstrak). ${ }^{8}$ Sedangkan menurut Romli SA. ${ }^{9}$ Istihsan secara bahasa adalah:

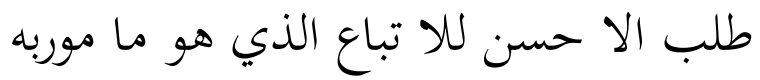

"Berusaha mendapatkan yang terbaik untuk diikuti bagi sesuatu masalah yang diperhitungkan untuk dilaksanakan".

Dalam pernyataan yang lain, ia juga menyatakan bahwa istihsan secara bahasa adalah:

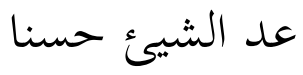

"Memperhitungkan bahwa sesuatu itu adalah baik".

Sedangkan menurut istilah, masih terdapat perbedaan rumusan dikalangan ulama Ushul Fiqh. Masing-masing ulama mempunyai rumusan dan batasan yang berbeda antara satu dengan yang lain. Oleh karena itu berikut ini akan dicantumkan beberapa definisi.

6 Muhammad Abu Zahrah, Ushul Fiqh, (Jakarta: PT. Pustaka Firdaus, 1994), hal. 401. Bandingkan dengan Saipudin Shidiq, Ushul Fiqh, Cetakan Ke 2, (Jakarta: Kencana, 2014), hal. 82.

${ }^{7}$ Departemen Agama Republik Indonesia, Ushul Fiqh I, (Jakarta: Direktorat Jenderal Pembinaan Kelembagaan Agama Islam, 1986), hal. 142.

8 Abdul Wahab Khallaf, Kaidah-kaidah Hukum Islam Ilmu Ushul Fiqh, (Jakarta: PT. Raja Grafindo Persada, 2000), hal. 117.

${ }^{9}$ Romli SA., Muqaranah Mazahib..., hal. 138. 
Ibn Al-Arabi, seorang ulama pengikut imam Malik, sebagai mana yang dikutip oleh Al-Shiddieqy, ${ }^{10}$ memberikan definisi istihsan adalah mengutamakan atau meninggalkan kehendak suatu dalil dengan cara istisna' (pengecualian), atau dengan cara mencari kelapangan karena ditentangi oleh suatu dalil yang menentanginya pada sebahagian kehendak dalil tersebut.

Sementara itu, Ibnul Anbary, seorang ahli fiqh dari mazhab Maliki, memberikan definisi bahwa "istihsan adalah memilih menggunakan maslahat juziyyah yang berlawanan dengan qiyas kully".11 Sebagaimana yang diinformasikan oleh T.M. Hasbi Al-Shiddieqy definisi ini seirama dengan definisi yang diberikan oleh Ibnu Rusyd, ia menyatakan bahwa istihsan itu adalah menggunakan qiyas mengakibatkan berlebih-lebihan dalam hukum, maka dia berpaling pada sebagian tempat tertentu karena ada suatu pengertian yang memberi bebas kepada hukum yang tertentu dari tempat itu saja. ${ }^{12}$

Istihsan juga mempunyai pengertian meninggalkan hukum yang telah ditetapkan pada suatu peristiwa atau kejadian yang ditetapkan berdasar dalil syara', menuju (menetapkan) hukum lain dari peristiwa atau kejadian itu juga, karena ada suatu dalil syara' yang mengharuskan untuk meninggalkannya.

Adapun Abdul Wahab Khallaf mengatakan bahwa istihsan adalah berpindahnya seorang mujtahid dari tuntutan qiyas jali (qiyas nyata) kepada qiyas khafi (qiyas samar). Atau dari hukum kulli (umum) kepada hukum pengecualian, karena ada dalil yang menyebabkan dia mencela akalnya, dan dimenangkan baginya perpindahan ini. ${ }^{13}$ Misalnya seseorang lupa apa yang ia lakukan, dan makan pada saat yang mestinya ia berpuasa, qiyas menyatakan bahwa puasanya menjadi batal, sebab pertimbangan kursial dalam qiyas adalah makanan telah masuk ke dalam kerengkongan (badan), terlepas apakan

${ }^{10}$ T.M. Hasbi Al-Shiddieqy (b), Pokok-pokok Pegangan Imam Mazhab, (Semarang: PT. Pustaka Rizki Putra, 1974), hal. 295.

${ }^{11}$ Muhammad Abu Zahrah, Ushul Fiqh..., hal. 402.

12 T.M. Hasbi Al-Shiddieqy (a), Falsafah Hukum..., hal. 295.

${ }^{13}$ Abdul Wahab Khallaf, Kaidah-kaidah.... 
disengaja atau tidak. ${ }^{14}$ Tetapi dalam kasus ini qiyas ditinggalkan berdasarkan atas sebuah hadits yang menyatakan bahwa puasa tetap sah bila makan tersebut disebabkan karena kesalahan (lupa).

Kalau diperhatikan secara teliti dari beberapa definisi di atas, maka dapat diambil pengertian bahwa para ulama ushul fiqh mazhab Maliki, mazhab Hanafi dan mazhab Hambali dengan berbagai macam definisi (formulasi) istihsan mereka telah mempunyai titik temu (sepakat) mengenai inti makna atau pengertian istihsan, yaitu berpindah dari suatu hukum kepada hukum lainnya, atau memilih suatu hukum dan mengenyampingkan (mengabaikan) hukum lainnya, atau mengecualikan hukum yang bersifat kulli dengan hukum yang bersifat $j u z^{\prime} i$, atau mengadakan takhsis terhadap hukum yang bersifat umum. Juga mereka telah sepakat tentang kebolehan memilih, berpindah, mengecualikan dan mengkhususkan hukum karena adanya dalil atau alasan lain yang menjadi dasar atau argumentasinya, baik dari nash Al-Quran dan Sunah, maslahat maupun urf. Argumentasinya atau dalil inilah yang oleh ulama ushul fiqh disebut sandaran istihsan.

Tegasnya, bahwa istihsan adalah pindah dari suatu hukum mengenai suatu masalah kepada hukum yang lain dalam mengatasi dan memutuskan permasalahan tersebut karena ada dalil syar'i (lain), yang mengharuskan demikian. Dalil syar'i ini disebut sandaran istihsan.

\section{Macam-macam Istihsan}

Untuk mengetahui tentang macam-macam istihsan (menurut ulamaulama yang mengakui istihsan sebagai dasar penetapan hukum Islam), dapat dilihat dari dua segi, yaitu: Pertama, macam-macam istihsan dipandang dari segi dalil (yang dipakai dan yang ditinggalkan atau diabaikan). Istihsan dipandang

${ }^{14}$ Wael B. Hallaq, Sejarah Teori Hukum Islam (Pengantar Ushul Untuk Ushul Fiqh Mazhab Sunni), (Jakarta: PT. Raja Grafindo Persada, 2000), hal. 160. 
dari segi dalil ini adalah mentarjih qiyas khafi daripada qiyas jali, karena ada dalil yang mendukungnya. Kedua, istihsan dipandang dari segi sanad atau sandaran istihsan. Istihsan dipandang dari segi sanad adalah memberlakukan pengecualian hukum juz'i dari hukum kulli atau kaidah umum, didasarkan pada dalil khusus yang mendukungnya. ${ }^{15}$

Macam-macam istihsan dipandang dari sudut dalil, maka istihsan tersebut dapat dibagi tiga bentuk, yaitu:

1. Memenangkan qiyas khafi atas qiyas jali dengan dalil.

2. Pindah dari pengertian nash yang umum kepada pengertian nash yang khusus.

3. Mengecualikan $j u z^{\prime} i$ dari hukum kulli dengan dalil. ${ }^{16}$

Untuk lebih mudah dimengerti gambaran di atas, berikut ini kami akan memberikan contoh-contoh dari masing-masing macam istihsan tersebut di atas.

1. Contoh istihsan memenangkan qiyas khafi atas qiyas jali yaitu:

a. Menurut Imam Hanafi, berdasarkan ketetapan qiyas maka hak pengairan dan jalan yang tidak disebutkan dalam akte wakaf tanah pertanian tidak termasuk dalam akte wakaf. Sedangkan berdasarkan ketetapan istihsan, maka hak pengairan, hak pemeliharaan dan hak jalan dapat dimasukkan kedalam wakaf, sekalipun tidak disebutkan dalam akte. Jadi kalau menurut qiyas jali, maka masalah wakaf ini diqiyaskan pada masalah jual beli. Oleh karena itu hak pengairan, pemeliharaan dan jalan tidak termasuk dalam wakaf. Akan tetapi menurut qiyas khafi, maka masalah wakaf ini diqiyaskan pada sewamenyewa. Berpindah dari qiyas jali kepada qiyas khafi inilah yang disebut istihsan. Jadi qiyas jali, yaitu menyesuaikan wakaf dalam soal ini dengan jual beli, karena masing-masing itu mengeluarkan hak

${ }^{15}$ Nasrun Haroen, Ushul Fiqh I, (Jakarta: Logos, 1996), hal. 105.

${ }^{16}$ Abdul Wahab Khallaf, Kaidah-kaidah..., 118. 
milik dari pemiliknya. Sedangkan qiyas khafi adalah menyesuaikan wakaf dalam soal ini dengan sewa-menyewa, karena dari masingmasing itu yang dimaksudkan adalah adalah mengambil manfaat. ${ }^{17}$

b. Menurut Imam Hanafi, berdasarkan qiyas jali, maka bekas minuman (patukan) burung buas adalah najis. Sebab diqiyaskan dengan hewan buas seperti burung garuda, burung gagak, dan burung elang yang dagingnya haram dimakan. Berdasarkan ketetapan qiyas khafi, maka bekas minuman (patukan) burung buas adalah suci, tidak najis karena burung tersebut minum dengan paruhnya. Berpindah dari qiyas jali kepada qiyas khafi inilah disebut dengan istihsan. ${ }^{18}$

2. Contoh istihsan pindah dari pengertian nash yang umum kepada pengertian yang khusus adalah berdasarkan pengertian umum ayat berkut ini:

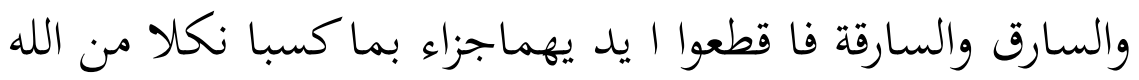

\section{(Q. 5. Al-Maidah: 38)}

Menurut ayat di atas, maka setiap pencuri baik laki-laki maupun perempuan hukumannya adalah potong tangan, tetapi berdasarkan pengertian khusus ayat, maka hukuman potong tangan tersebut ditiadakan. Hal ini dapat dilakukan pemahaman khusus pada masa (ketika) pacekelik atau musim kelaparan di masa khalifah Umar Ibn Khattab. Menurut Umar, kalau dalam keadaan yang demikian hukuman potong tangan diterapkan dapat menimbulkan bahaya terhadap umat. Paling tidak umat akan mendapatkan salah satu dari dua bahaya berikut. Pertama, bila mereka tetap menahan diri untuk tidak mencuri, maka dapat dipastikan mereka akan menderita kelaparan yang berkepanjangan yang dapat merenggut jiwanya atau merusak

${ }^{17} \mathrm{Ibid}$.

${ }^{18}$ Muhammad Abu Zahrah, Ushul Fiqh..., hal. 408. 
kesehatannya. Kedua, karena sangat terpaksa, mereka tetap saja mencuri. ${ }^{19}$

Dari kasus ini terlihat jelas bahwa Umar berpaling dari suatu ketentuan hukum kepada ketentuan hukum yang lain dalam penerapannya. Artinya bila suatu ketentuan hukum dalam penerapannya tidak mampu merealisasi dan memelihara maqashid alsyari'at, maka dalam keadaan yang demikian sajalah Umar berpaling dari ketentuan hukum tersebut kepada ketentuan hukum yang lain yang lebih mampu merealisasi dan memelihara Maqashid Al-Syari'at itu.

3. Contoh istihsan mengecualikan juz'i dari hukum kulli adalah menurut hukum kulli, seseorang yang diberi amanat, wajib mengganti atas hilangnya barang yang dititipkan kepada pihak penitipnya, bila si penitip itu meninggal dunia. Sebab dengan hilangnya barang tersebut berarti ia tidak berhati-hati atau sembrono dalam memelihara barang tersebut.

Dalam masalah ini, dikecualikan apabila yang menghilangkannya itu ayah atau nenek dari yang punya harta. Dalam pada itu ayah atau nenek mempunyai hak penuh terhadap harta anaknya sendiri, jadi si ayah atau nenek tidak diwajibkan mengganti harta yang hilang adalah berdasarkan ketetapan istihsan. Dengan kata lain, berpindahnya dari hukum kulli kepada hukum juz'i inilah disebut istihsan.

Memperhatikan eksistensi istihsan sebagai dalil hukum dipandang dari sudut sanad (sandaran), ternyata dikalangan ulama mazhab dibagi kepada beberapa macam.

1. Menurut Imam Hanafi

19 Iskandar Usman, Istihsan dan Pembaharuan Hukum Islam, (Jakarta: PT. Raja Grapindo Persada, 1994), hal. 197. 
Dalam pandangan Imam Hanafi, seperti dalam penjelasan Muhammad al-Said Ali Abd. Rabuh, bahwa istihsan dibagi kepaa lima macam yaitu:

a. Disebut istihsan dengan nash.

Yang dimaksud dengan istihsan jenis ini ialah penyimpangan suatu ketentuan hukum berdasarkan ketetapan qiyas kepada ketentuan hukum yang berlawanan dengan yang ditetapkan berdasarkan nash Al-Quran dan hadits.

العد ول عن حكم القياس فى مسئلة الى حكم مخا لف له ثبت با لكتاب

Istihsan jenis ini, sering ditemui dalam beberapa masalah yang bersumber dari nash yang sudah pasti berlawanan dengan ketentuan hukum yang umum atau kaidah yang sudah berlaku. Contoh kasus orang yang makan dan minum karena lupa ketika ia sedang berpuasa. Menurut kaidah umum (qiyas), puasa orang ini batal karena ia telah memasukkan sesuatu ke dalam kerengkongannya dan tidak menahan puasanya sampai berbuka. Akan tetapi, hukum ini dikecualikan oleh hadits atau sunnah Rasulallah Saw. berikut ini:

$$
\text { ...من اكل اوشرب ناسيا فلا يغطر فا نما هورزق رزقه الله... }
$$


Hadits ini menjelaskan bahwa orang yang makan dan minum tanpa disengaja pada saat ia sedang puasa maka hal tersebut tidak membatalkan puasanya. ${ }^{20}$

b. Disebut istihsan dengan ijma'.

Yang dimaksud dengan istihsan jenis ini adalah meninggalkan keharusan menggunakan qiyas pada suatu persoalan karena ada ijma'. Hal ini terjadi karena adanya fatwa mujtahid atas suatu peristiwa yang berlawanan dengan pokok atau kaidah umum yang telah ditetapkan, atau para mujtahid bersikap diam dan tidak menolak apa yang dilakukan oleh manusia (masyarakat), yang sebetulnya berlawanan dengan dasar-dasar pokok yang telah ditetapkan. Sedangkan contoh istihsan jenis ini adalah pesanan seseorang kepada orang lain untuk dibuatkan sesuatu barang. Transaksi seperti ini disebut dengan " "عقد الا ستصناع . transaksi seperti ini adalah seseorang meminta kepada seseorang tukang untuk dibuat sesuatu barang tertentu, dengan syarat-syarat tertentu, yang sebetulnya tidak boleh dilakukan, karena ketika berlangsungnya transaksi tersebut, barang pesanan itu belum ada wujudnya (ma'dum), sementara transaksi atas barang yang belum ada wujudnya tidak dibolehkan menurut qiyas. Akan tetapi, berdasarkan istihsan, transaksi (akad) seperti ini dibolehkan meskipun berlawanan dengan ketentuan qiyas, karena hal seperti ini dalam praktik (muamalah) masyarakat telah berjalan tanpa ada penolakannya dari ahli Ijtihad (mujtahid). ${ }^{21}$

${ }^{20}$ Nasrun Haroen, Ushul Fiqh..., hal. 108.

${ }^{21}$ Romli SA., Muqaranah Mazahib..., hal. 145. 
c. Disebut istihsan dengan darurat dan hajat.

Yang dimaksud dengan istihsan jenis ini adalah seorang mujtahid meninggalkan keharusan pemberlakuan qiyas atas sesuatu masalah karena berhadapan dengan kondisi darurat, dan mujtahid berpegang kepada ketentuan yang mengharuskan untuk memenuhi hajat atau menolak terjadinya kemudaratan.

Dengan kata lain, karena adanya penolakan yang bersifat darurat dan menjadi hajat orang banyak, maka penetapan yang semestinya didasarkan pada qiyas terpaksa ditinggalkan. Sebagai contoh, sumur atau kolam yang terkena najis. Berdasarkan kaidah umum bahwa sumur atau kolam yang terkena najis itu tidak boleh digunakan. Akan tetapi, karena kondisi darurat yang menghendakinya dan air itu sangat dibutuhkan, maka dalam kondisi seperti ini dibolehkan, meskipun berlawanan dengan kaidah umum atau adanya dalil yang melarangnya. Menurut kalangan mazhab Hanafi untuk menghilangkan najis itu cukup dengan memasukkan beberapa galon air kedalam kolam atau sumur tersebut, karena kondisi darurat yang dihadapi agar orang tidak menemukan kesulitan untuk memenuhi kebutuhan terhadap air.

d. Disebut istihsan dengan urf dan adat.

Yang dimaksud dengan istihsan jenis ini adalah penyimpangan atau pemalingan penetapan hukum yang berlainan (berlawanan) dengan ketentuan qiyas, karena adanya 'urf yang sudah biasa dipraktikkan dan sudah dikenal dalam kehidupan masyarakat. Istihsan jenis ini sangat banyak digunakan dalam berbagai adat kebiasaan 
masyarakat yang menyalahi ketentuan qiyas atau kaidah umum yang berlaku. Sebagai contoh adalah mewakafkan benda bergerak. Menurut kaidah, wakaf itu harus benda tidak bergerak, mudah hilang dan rusak. Tetapi karena 'urf telah berlaku demikian, maka dibolehkan untuk menghindari pertengkaran. Karena ini pula golongan Hanafiyah membenarkan segala syarat yang diterima 'urf asal saja tidak membatalkan sesuatu nash syara'.22

e. Disebut istihsan dengan qiyas khafi.

Yang dimaksud dengan istihsan jenis ini adalah memalingkan suatu masalah dari ketentuan hukum qiyas yang jelas kepada ketentuan hukum qiyas yang samarsamar dan tidak jelas, tetapi keberadaannya lebih kuat dan lebih tepat untuk diamalkan. Sebagai contoh adalah tentang aurat wanita. Sesungguhnya aurat wanita itu adalah mulai dari ujung kepala sampai kepada ujung kakinya, kemudian dibolehkan bagian tubuhnya sekedar dibutuhkan, untuk keselamatan dan kebaikan perempuan tersebut. Hal seperti ini terdapat perlawanan antara dua qiyas, yang pertama ditetapkan berdasarkan kaidah yang jelas tentang keadaan wanita melihatnya bisa menimbulkan fitnah, dan yang kedua adanya suatu keadaan yang menimbulkan masyaqah (keadaan yang mendesak) dalam beberapa keadaan seperti pengobatan ketika tidak ada wanita yang khusus untuk itu, maka digunakanlah 'illat (alasan) yang membawa kepada kemudaratan pada bagian ini.

${ }^{22}$ T.M. Hasbi al-Shiddieqy (a), Falsafah Hukum..., hal. 299. 
Berdasarkan pandangan yang berkembang dalam mazhab Hanafi, bahwa kasus yang disebut terakhir ini menunjukkan justru lebih penting, meskipun keadaannya samar-samar dan berlawanan dengan qiyas zahir, tetapi 'illatnya lebih kuat dan lebih besar pengaruhnya karena kebutuhan yang tidak bisa dielakkan.

\section{Biografi Imam Hanafi}

Dalam sejarah tasyri' Islam, Imam Hanafi tercatat sebagai salah satu imam mazhab diantara imam-imam mazhab lainnya. Nama lengkapnya adalah Nu'man bin Tsabit bin Zauthi bin Mah. Beliau dilahirkan di Kuffah, kota yang terletak di Irak pada tahun 80 Hijriyah atau bersamaan dengan tahun 699 Masehi. ${ }^{23}$ Tetapi dalam riwayat lain di ceritakan, bahwa Imam Hanafi dilahirkan pada tahun 81 Hijriyah, atau bersamaan dengan tahun 700 Masehi. Sebagaimana Abdurrahman mengemukakan bahwa Imam Hanafi dilahirkan pada tahun $81 \mathrm{H} / 700 \mathrm{M}$ di Kuffah (w. $150 \mathrm{H}) .{ }^{24}$

Ayahnya (Tsabit bin Zauti bin Mah) adalah keturunan bangsa Persi, yaitu Kabul dan Afghanistan. Tetapi sebelum Nu'man lahir ayahnya sudah pindah ke Kuffah. Pada masa itu pemerintahan Islam sedang mengalami peralihan dari Bani Umayyah kepada Bani Abbas. Ketika itu kota Kuffah merupakan markas terbesar yang hendak menggulingkan kekuasaan Bani Umayyah. ${ }^{25}$

Menurut riwayat diceritakan bahwa Tsabit (Ayah Nu'man atau Imam Hanafi) ketika masih kecil diajak ayahnya (Zauti bin Mah) berkunjung kepada Ali bin Abi Thalib Ra., ketika itu Ali mendo'akan: “Mudah-mudahan diantara keturunannya ada yang menjadi orang yang baik-baik serta luhur budinya".

${ }^{23}$ Asef Saifuddin Al-Mansur, Kedudukan Mazhab dalam Syari'at Islam, (Jakarta: Pustaka AlHusna, 1984), hal. 45.

${ }^{24}$ Abdurrahman, Perbandingan Mazhab, (Bandung: Sinar Baru, 2011), hal. 24.

25 Ibid. 
Ternyata salah seorang dari keturunannya yang bernama Nu'man menjadi seorang ulama besar dan sangat luas pengetahuannya, yang kemudian lebih dikenal dengan nama Imam Hanafi.

Lebih lanjut T.M. Hasbi Al-Shiddieqy mengemukakan, bahwa Imam Hanafi adalah anak dari saudagar (pedagang) besar di kota Kuffah sehingga semasa kecil Imam Hanafi tidak mengalami kesulitan dibidang ekonomi dalam memenuhi kebutuhan hidup. Karena kelapangan ekonomi tersebut, maka Imam Hanafi mempergunakannya dengan baik dan sungguh-sungguh untuk menuntut ilmu pengetahuan hingga dewasa. ${ }^{26}$

Sebagaimana dikemukakan oleh Abdurrahman ${ }^{27}$ bahwa Imam Hanafi berada pada suatu tempat yang mana tempat tersebut minimnya orang-orang yang mengetahui tentang sunah dibandingkan dengan lainnya yang terkenal. Lebih dari itu pada masa Imam Hanafi banyak terdapat orang-orang yang tidak mempercayai Rasulullah Saw. sehingga banyak sunnah yang dibuat-buat sendiri dan terjadilah perpecahan diantara orang-orang dimasa itu. Sedangkan masalah-masalah hukum yang penyelesaiannya tidak diperoleh keterangan dari dalam Al-Quran, al-Hadits atau sunnah ataupun pendapat para sahabat selalu muncul setiap waktu. Karena situasi itu juga, maka mulailah Imam Hanafi mencurahkan segala kemampuannya dengan akal (pikiran) dalam menggali dalil dari nash Al-Quran dan al-Hadits atau sunnah untuk menetapkan hukum yang bersangkutan.

Menurut para ahli sejarah, penyebab mulai timbulnya usaha-usaha untuk menyatukan antara nash-nash agama dengan kehidupan sekular antara lain karena kekayaan dan perkembangan ilmu pengetahuan amat pesat yang meliputi hampir sekuruh negeri Arab khususnya kota Baghdad (Ibu Kota Negara Iraq). Keadaan tersebut menyebabkan Iraq terkenal sebagai pusat sukusuku ahli pikir. Karena situasi itulah Imam Hanafi terpengaruh oleh pendapat-

${ }^{26}$ T.M. Hasbi Al-Shiddieqy (b), 1974. Pokok-pokok..., hal. 476.

${ }^{27}$ Abdurrahman, Perbandingan Mazhab..., hal. 26. 
pendapat ahli pikir tersebut yang kemudian terkenal sebagai seorang ahli dalam ilmu Fiqh dan ketua kelompok ahli pikir.

Keluasan ilmu pengetahuan imam Hanifah menjadikannya seorang ulama terkenal sampai saat ini. Bahkan dalam perkembangan sejarah ia mempunyai pengaruh yang besar sehingga banyak pengikut-pengikutnya yang menyebut ia dengan ulama mazhab Hanafi.

\section{E. Dasar Istinbath Hukum Imam Hanafi}

Dalam mengistimbathkan hukum, Imam Hanafi sebagaimana imamimam mazhab lainnya mendasari setiap penetapan suatu hukum dari sebuah persoalan menggunakan dasar-dasar yang terdapat dalam sumber-sumber yang valid dan kuat. Bahkan kepada murid-muridnya, Imam Hanafi memberikan kebebasan untuk berpikir dan menggali hukum-hukum dari AlQuran. Baik tidak ada di dalam Al-Quran maka beliau menyuruh muridmuridnya untuk mencari hadits-hadits Rasulallah Saw. dan beliau sangat melarang murid-muridnya bertaqlid.

Hal tersebut di atas merupakan gambaran, bahwa Imam Hanafi tidak sembarangan dalam menggali dan mengeluarkan hukum-hukum dalam memecahkan masalah-masalah keagamaan. Pemikiran Imam Hanafi ini berdasarkan sumber yang kuat dan terpercaya. Secara hirarkis, Imam Hanafi menggali hukum-hukum untuk menyelesaikan berbagai masalah keagamaan sebagai berikut:

1. Al-Quran

2. Sunah

3. Pendapat Para Sahabat

4. Al-Ijma'

5. Al-Qiyas

6. Al-Istihsan 
7. Al-Urf.28

Imam Hanafi dalam menetapkan hukum, pertama-tama merujuk kepada Al-Quran. Bila tidak ditemui dalam Al-Quran, maka ia mencari dasar hukumnya melalui sunah Rasulallah Saw. Jika tidak ditemui sunah-sunah yang dapat dijadikan sandaran hukum, ia merujuk kepada fatwa-fatwa para sahabat Rasulallah Saw. yang telah disepakati dan ijma' mujtahidin. Jika tidak ditemui, maka ia menggunakan segala kemampuannya dengan Al-Qiyas, Al-Istihsan dan Al-Urf (adat kebiasaan manusia).

\section{F. Eksistensi Istihsan Dalam Istinbath Hukum Menurut Persfektif Imam Hanafi}

Imam Hanafi banyak menetapkan hukum dengan istihsan, tetapi ia tidak pernah menjelaskan pengertian dan rumusan dari istihsan yang dilakukannya itu secara ekplisit. Istihsan menurut bahasa, sebagaimana telah dijelaskan, berarti menganggap atau memandang baik terhadap sesuatu. ${ }^{29}$ Karena Imam Hanafi tidak menjelaskan pengertian dan rumusan dari istihsan itu, maka orang mengatakan bahwa ia hanya menetapkan hukum menurut keinginannya saja tanpa memakai metode. Asal sudah dipandang baik sudah bisa menjadi dasar penetapan hukum, karena demikianlah arti yang ditunjukkan oleh istihsan itu.

Dalam persoalan ini banyak fukaha yang tidak mengetahui hakikat istihsan yang dipraktekkan oleh Imam Hanafi, oleh karena itu, menurut Husain Hamid Hasan sebagaimana diinformasikan oleh Iskandar Usman berpegangnya Imam Hanafi kepada istihsan menjadi sumber kritik terhadapnya, bahkan sampai kepada mencelanya sebagai orang yang tidak mengerti fiqh dan meragukan kewarakannya. ${ }^{30}$

\footnotetext{
${ }^{28}$ Ahmad Al-Syurbasi, Sejarah dan Biografi Empat Imam Mazhab (Hanafi, Maliki, Syafi'i dan Hambali), (Jakarta: PT. Bumi Aksara, 1991), hal. 19.

${ }^{29}$ Romli SA., Muqaranah Mazahib..., hal. 139.

${ }^{30}$ Iskandar Usman, Istihsan dan..., hal. 44.
} 
Setelah timbul kritik-kritik itu, maka para sahabat Imam Hanafi dan pengikutnya berusaha menjelaskan pengertian dan rumusan istihsan yang banyak dilakukan oleh imam mereka. Mereka berusaha menjelaskan bahwa sesungguhnya istihsan itu tidak keluar dari dalil-dalil syara'.

Sebagian ulama hanafiah seperti Al-Sarkhsi, sebagaimana diinformasikan oleh Muhammad Abu Zahrah,31 menyatakan bahwa istihsan pada hakekatnya adalah dua qiyas. Pertama, qiyas jali (jelas) tetapi dhaif (lemah) pengaruhnya. inilah yang dinamakan mereka dengan qiyas. sedangkan yang kedua, qiyas khafi (samar) tetapi kuat pengaruhnya. Hal ini kemudian mereka namakan dengan istihsan, yaitu qiyas mustahsan. Maka di sini yang diutamakan adalah pengaruhnya (atsarnya), bukan samar atau jelasnya sifat.

Dari sejumlah literatur menyebutkan bahwa kelompok yang berhujjah dan menggunakan istihsan sebagai dalil hukum, sebagaimana dijelaskan oleh Romli SA. ${ }^{32}$ adalah terdiri dari mazhab Hanafi, mazhab Maliki dan mazhab Hambali. Dalam pandangan kelompok yang menggunakan istihsan ini mereka menyatakan bahwa istihsan itu adalah salah satu dalil hukum syara', dan istihsan ini mereka pergunakan dalam menyelesaikan berbagai macam bentuk persoalan ketika persoalan tersebut berlawanan dengan qiyas atau kaidah nash umum yang berlaku.

Penggunaan istihsan yang dipraktekkan oleh Imam Hanafi tidaklah keluar dari nash syara' dan bahkan dikatakan penggunaan istihsan ini merupakan bagian dari dalil syara' selain dari nash yang tertulis. Selain itu juga bahwa istihsan merupakan salah satu dasar istinbath hukum dalam mazhab Hanafi dan mazhab Maliki.

Adapun landasan hukum yang digunakan oleh Imam Hanafi dalam rangka penggunaan istihsan sebagai dasar istinbath hukum adalah nash Al-

\footnotetext{
${ }^{31}$ Muhammad Abu Zahrah, Ushul Fiqh..., hal. 405.

${ }^{32}$ Romli SA., Muqaranah Mazahib..., hal. 151.
} 
Quran, sunnah atau hadits, dan ijmak. Dalil-dalil tersebut adalah sebagai berikut:

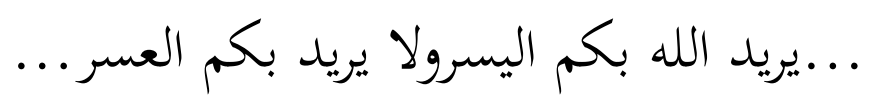

(Q. 2 Al-Baqarah: 185)

$$
\text { الذ ين يستمعون القول فيتبعون احسنه اولئك الذ ين هدا هم الله.... }
$$

(Q. 39 Al-Zumar: 18)

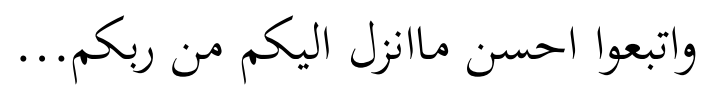

(Q. 39 Al-Zumar: 55)

Dalam ayat pertama di atas bahwasanya Allah Swt. menghendaki kemudahan dan bukan kesulitan dalam rangka mewujudkan kebaikan dan kemaslahatan bagi manusia. Sedangkan pada ayat kedua dan ketiga tersebut, menurut kelompok yang menjadikan istihsan sebagai dasar dalam istinbath hukum menyatakan bahwasanya Allah Swt. memuji orang-orang yang mengikuti pendapat yang paling baik dan bahkan pula Allah Swt. memerintahkan untuk mengikuti yang paling baik dari apa-apa yang telah diturunkan oleh-Nya.

Dapat ditegaskan disini, bahwa pada ayat pertama tersebut dinyatakan bahwa Allah Swt. memberikan kemudahan bagi manusia dalam menyelesaikan berbagai macam persoalan yang dihadapi oleh manusia. Sedangkan pada ayat berikutnya Allah Swt. memerintahkan untuk mengikuti dan melaksanakan yang terbaik dalam rangka menciptakan kemaslahatan bagi kehidupan manusia.

Sedangkan sunah atau hadits yang mereka jadikan dalil adalah sunnah atau hadits berikut ini, yaitu: 


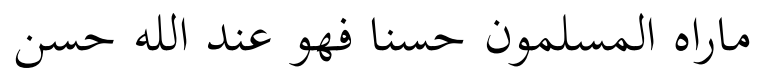

Hadits atau sunnah ini mengisyaratkan kepada kita bahwa, setiap apa yang dianggap baik oleh kaum muslimin, maka hal tersebut mempunyai nilai baik juga dihadapan Allah Swt. Namun, segala sesuatu yang dianggap baik oleh kaum muslimin tersebut harus dijiwai oleh nash-nash, baik itu berupa AlQuran, sunnah atau hadits, ijma', maupun qiyas, agar segala sesuatu yang timbul nantinya tidak keluar dari syari'at yang ada.

Adapun ijmak yang mereka jadikan landasan hukum tentang penggunaan istihsan ini adalah ijmak ulama terhadap masalah pemakaian kamar mandi umum tanpa disebutkan lamanya masa pemakaian dan banyaknya air yang digunakan. ${ }^{33}$

Dari dalil-dalil yang diketengahkan oleh Imam Hanafi di atas, maka jelaslah bahwa dalil-dalil tersebut merupakan dasar pijakan penggunaan istihsan dalam salah satu dasar istinbath hukum. Sehingga istihsan yang digunakan oleh Imam Hanafi tidak keluar dari nilai-nilai syari'at. Maka dasar hukum atau berdalil dengan istihsan ini diharapkan memelihara kemaslahatankemaslahatan yang didukung oleh nash-nash syari'at, baik dengan nash tertentu maupun dengan pengertian suatu nash atau dengan pengertian sekelompok nash yang memberikan suatu pengertian yang sama.

\section{G. Kesimpulan}

Dari deskripsi tulisan di atas dapat disimpulkan bahwa penggunaan istihsan dalam melakukan istinbath hukum yang dipraktekkan oleh imam Hanafi merupakan salah satu upaya ijtihad (pengembangan dua dalil yang bertentangan) yang ia lakukan dalam rangka pengembangan metodologi hukum Islam yang bersifat global. Sehingga dalam menyikapi persoalan-

\footnotetext{
${ }^{33}$ Iskandar Usman, Istihsan dan..., hal. 63.
} 
persoalan yang bersifat klasik maupun kontemporer, hukum Islam diharapkan dapat dirasakan dinamis. Penggunaan istihsan dalam istinbath hukum yang dilakukan oleh imam Hanafi ini, merupakan suatu upaya mentarjih (menganggap kuat) salah satu dari dua dalil yang bertentangan karena dipandang lebih dapat menjangkau tujuan pembentukan hukumnya. 


\section{DAFTAR PUSTAKA}

Al-Qur'an Nul Qarim

Abdurrahman. 1991. Perbandingan Mazhab. Bandung: Sinar Baru

Chalil, Moenawar. 1955. Biografi Empat Serangkai Imam Mazhab. Jakarta: Bulan Bintang

Departemen Agama Republik Indonesia. 1986. Ushul Figh I. Jakarta: Direktorat Jenderal Pembinaan Kelembagaan Agama Islam

Effendi, Satria. 2014. Ushul Fiqh. Cetakan Ke 5. Jakarta: Kencana

Hallaq, Wael B. 2000. Sejarah Teori Hukum Islam (Pengantar Ushul Untuk Ushul Figh Mazhab Sunni). Jakarta: PT. Raja Grafindo Persada

Haroen, Nasrun. 1996. Ushul Figh I. Jakarta: Logos

Khallaf, Abdul Wahab. 2001. Sejarah Pembentukan dan Perkembangan Hukum Islam. Jakarta: PT. Raja Grafpindo Persada

2000. Kaidah-Kaidah Hukum Islam Ilmu Ushul Fiqh. Jakarta: PT. Raja Grafindo Persada

Al-Mansur, Asef Saifuddin. 1984. Kedudukan Mazhab dalam Syari'at Islam. Jakarta: Pustaka al-Husna

Romli SA. 1999. Muqaranah Mazahib Fil Ushul. Jakarta: Gaya Media Pratama

Al-Shiddieqy, T.M. Hasbi. 2001. Falsafah Hukum Islam. Semarang: PT. Pustaka Rizki Putra

1974. Pokok-Pokok Pegangan Imam Mazhab. Semarang: PT. Pustaka Rizki Putra

Shidiq, Saipudin. 2014. Ushul Fiqh. Cetakan Ke 2. Jakarta: Kencana.

Al-Syurbasi, Ahmad. 1991. Sejarah dan Biografi Empat Imam Mazhab (Hanafi, Maliki, Syafi'i dan Hambali). Jakarta: PT. Bumi Aksara 
Eksistensi Istihsan dalam Istinbath Hukum

Usman, Iskandar. 1994. Istihsan dan Pembaharuan Hukum Islam. Jakarta: PT. Raja Grapindo Persada

Zahrah, Muhammad Abu. 1994. Ushul Fiqh. Jakarta: PT. Pustaka Firdaus 